\title{
Adapting Existing Assessment Tools For Use in Assessing Engineering Graduate Attributes
}

\author{
Alan Chong and Lisa Romkey \\ University of Toronto \\ alan.chong@utoronto.ca,romkey@ecf.utoronto.ca,
}

\begin{abstract}
Recently, changes to the Canadian Engineering Accreditation requirements, following the example set by ABET, have called for the measurement of 12 graduate attributes in the engineering curriculum. Some attributes, such as "Knowledge Base," lend themselves to forms of quantitative measurement; others, such as "Investigation" and "Communication" are inherently difficult to measure quantitatively and comprehensively. To assess these attributes authentically within our current curriculum, methods for adapting existing tools - that both satisfy the objectives of the actual course and the needs of graduate attributes assessment - must be found.

This paper describes the process and challenges involved in adapting existing tools for assessment to measure such graduate attributes, specifically in a large senior research thesis course in a multidisciplinary engineering program. These challenges include balancing both the needs of multiple parties involved in the assessment, maintaining rubric usability, reliability and validity, as well as appropriately matching rubric elements to attributes. Despite these tensions, the results provided by this process provide insight about rubric design, assessment strategies and the students' strengths and weaknesses within the graduate attributes, providing valuable information to feed back into the graduate attribute and continual curriculum improvement processes.
\end{abstract}

Keywords: Rubrics, Graduate Attributes, Assessment, Thesis, Undergraduate Research, Accreditation

\section{INTRODUCTION}

Recent changes to the Canadian Engineering Accreditation requirements, following the example set by ABET, have called for the measurement of 12 graduate attributes in the engineering curriculum [4]. Some attributes, such as "Knowledge Base," lend themselves to quantitative measurement; others, such as "Investigation" and "Communication" are inherently difficult to measure quantitatively and comprehensively. For these attributes, a major issue involves identifying an appropriate experience in which to measure them.

Ideal places to perform such measurement may include the one or more significant "capstone" experiences included in many undergraduate engineering programs, designed to give students an opportunity to demonstrate significant learning through the integration of knowledge and skills from across the degree $[1,6]$. Such a learning experience, an independent research project required for all senior students in a large, Canadian multi-disciplinary engineering program, forms the context for this paper. This thesis course gives senior undergraduate students an opportunity to work with a faculty member to define and design an original research project, as well as to conduct and communicate engineering-related research. In the 2010-11 school year, nearly 200 students in the program worked with 112 unique supervisors from 22 distinct academic departments, and across theoretical, clinical, design and laboratory settings, demonstrating a vast breadth of project scope. Outside of the studentsupervisor relationship, students are provided with assignment guidelines, workshops, and rubrics to scaffold the documentation and communication of the research, which includes four deliverables: a proposal, an interim report, presentation and final research report. The stated learning objectives, taken from the course syllabus, are as follows:

1. Write a strong research proposal, identifying and developing a gap in a science/engineering related field, and develop a plan/method for addressing that gap

2. Conduct and write a literature review, summarizing the state of a science/engineering related field

3. Execute a major, independent research project in a relevant field of study

4. Generate and analyze data as part of a major research project

5. Present research methods, designs, results, and claims effectively, orally and in writing 
6. Incorporate feedback from a variety of audiences to help improve the communication of scientific ideas

Given that the undergraduate thesis is a requirement for all students in the program, and that it capitalizes on students' earlier work in engineering communication and experimentation, it provides an excellent opportunity to measure students' skills in these areas at graduation. Capstone experiences, because of these characteristics [45], and as they exist in most undergraduate engineering programs $[1,6]$ are often used for program assessment purposes. In our case, it also presents an ideal opportunity to explore the adaptation of assessment tools for graduate attributes purposes, given that a newly developed common rubric for assessing all thesis projects had recently been completed [5]. Using a thesis course for attribute assessment purposes, however, presents some unique challenges that do not apply to capstone design course; for example, the large number of different assessors and diversity of projects.

Through this paper, we set out to answer the following research questions:

1) How can a complex, multidisciplinary undergraduate thesis course be used for the measurement of graduate attributes?

2) How can existing assessment tools be used and/or adapted for the graduate attributes process?

More specifically, this paper describes the adaptation of the rubric as an assessment tool designed to provide flexibility to a diverse group of projects and supervisors, as well as a tool worthy of utilizing in the graduate attribute assessment process, which should demonstrate how a cohort performs across the various indicators, or learning outcomes, that comprise an attribute. Yet while a seemingly ideal place for graduate attribute assessment, developing a rubric capable of generating useful data for these two sometimes competing purposes posed significant challenges, especially in relation to ensuring rubric validity and reliability. These challenges included mapping newly defined attributes to an existing assessment scheme, covering a diversity of projects in a large and complex undergraduate learning experience, as well as developing methods for addressing questions of inter-rater reliability within a large assessment team. Despite these tensions, the results provided by this process provide insight about the rubric design, assessment strategies and the students' strengths and weaknesses within the two graduate attributes, providing valuable information to feed back into the curriculum and thesis experience. The process of assessing graduate attributes within a curricular context also demonstrates the importance in allowing major curricular components to help define the learning outcomes associated with the graduate attributes, rather than relying only on a topdown process, focused on centrally-developed learning outcomes.

\section{ENGINEERING GRADUATE ATTRIBUTE DEVELOPMENT}

The Canadian Engineering Accreditation Board (CEAB) has outlined 12 graduate attributes, which describe both the engineering knowledge base, and engineering-related skills expected of graduates. Programs are required to demonstrate that students are graduating with the demonstrated attributes, and that a continual improvement process is in place, "that demonstrate(s) that program outcomes are being assessed in the context of the graduate attributes, and that the results are applied to the further development of the program" [4]. The CEAB has described the investigation and communication attributes as follows:

Investigation: an ability to conduct investigations of complex problems by methods that include appropriate experiments, analysis and interpretation of data, and synthesis of information in order to reach valid conclusions

Communication Skills: An ability to communicate complex engineering concepts within the profession and with society at large. Such ability includes reading, writing, speaking and listening, and the ability to comprehend and write effective reports and design documentation, and to give and effectively respond to clear instructions.

Engineering schools across Canada are working to develop their own desired learning outcomes associated with each of the Graduate attributes [7]. At the University of Toronto, a Faculty-wide Graduate Attribute Committee was constructed to further develop learning objectives associated with each of the 12 graduate attributes. The Graduate Attribute Committee, or GAC, includes representation from all undergraduate programs along with the Engineering Communication Program, first year and undergraduate studies officers, and graduate studies. The committee members hold strong engineering, teaching and administrative experiences.

Within the committee, learning objectives were developed at two levels: first, a few global outcomes were developed to describe the broader objectives associated with an attribute. Secondly, more specific "indicators" were developed for each of the global outcomes, which were designed to more precisely measure student learning in a specific course or assignment context. This process was followed because it was found to be difficult to move directly from the attributes provided by the CEAB, which 
are quite general, to clear, measurable outcomes that can be applied directly to a learning experience. This process assisted the committee in better developing a shared definition of each Attribute, and provided all working group members - and their respective departments and units - with a clear and shared understanding of each attribute. The process developed and carried out by the Graduate Attributes Committee has lead to a lot of useful discussion, and reflection, on what we are teaching, and what we need to be teaching.

The Graduate Attributes Committee commissioned a series of expert subcommittees to develop global outcomes and indicators for each of the 12 graduate attributes. In the case of the Communication attribute, faculty from the Engineering Communication Program developed a set of indicators, and in the case of Investigation, a group of cross-disciplinary faculty members who are active in research and teaching - and in particular the teaching of investigative laboratories served on the expert committee. The expert groups brought their suggested outcomes and indicators back to the entire Graduate Attributes Committee for review. The committee required at least three passes through in order to converge on a clear set of indicators for each attribute. The Global Outcomes and Indicators for Investigation and Communication are listed below, in Tables 1 and 2 .

Table 1: Investigation global outcomes and indicators

\begin{tabular}{|c|c|}
\hline $\begin{array}{l}\text { Global } \\
\text { Objectives }\end{array}$ & Indicators \\
\hline $\begin{array}{l}\text { Ability to define } \\
\text { the problem }\end{array}$ & $\begin{array}{l}\text { - State the problem, its scope and } \\
\text { importance } \\
\text { - } \\
\text { - } \quad \text { Sescribe the previous work } \\
\text { State objective of the work }\end{array}$ \\
\hline $\begin{array}{l}\text { Ability to devise } \\
\text { and execute a } \\
\text { plan to solve the } \\
\text { problem }\end{array}$ & $\begin{array}{l}\text { - } \\
\text { - } \\
\text { Select a set of tests to be conducted } \\
\text { collecting the results } \\
\text { - } \\
\text { Identify limitations of the methods used } \\
\text { and their impact on the results. }\end{array}$ \\
\hline $\begin{array}{l}\text { Ability to use } \\
\text { critical analysis } \\
\text { to reach valid } \\
\text { conclusions } \\
\text { supported by the } \\
\text { results of the } \\
\text { plan }\end{array}$ & $\begin{array}{ll}\text { - } & \text { Analyze the results } \\
\text { - } & \text { Formulate the conclusions } \\
\text { - } & \text { Validate conclusions by induction or } \\
\text { - } & \text { Coduction } \\
\text { - } & \text { Characterize the limitations and } \\
\text { implications of the conclusions }\end{array}$ \\
\hline
\end{tabular}

Table 2: Communication global outcomes and indicators

\begin{tabular}{|l|l|}
\hline $\begin{array}{l}\text { Global } \\
\text { Objectives }\end{array}$ & Indicators \\
\hline
\end{tabular}

\begin{tabular}{|c|c|}
\hline $\begin{array}{l}\text { Ability to } \\
\text { identify and } \\
\text { credibly } \\
\text { communicate } \\
\text { engineering } \\
\text { knowledge }\end{array}$ & $\begin{array}{l}\text { - Situate, in document or presentation, the } \\
\text { solution or design in the world of existing } \\
\text { engineering, taking into account social, } \\
\text { environmental, economic and ethical } \\
\text { consequences } \\
\text { - Recognize a credible argument (reading) } \\
\text { - Construct a credible argument in written or } \\
\text { spoken form - to persuasively present } \\
\text { evidence in support of a claim } \\
\text { Organize written or spoken material- to } \\
\text { structure overall elements so that their } \\
\text { relationship to a main point and to one } \\
\text { another is clear } \\
\text { - Create "flow" in document or presentation - } \\
\text { flow is a logical progression of ideas, } \\
\text { sentence to sentence and paragraph to } \\
\text { paragraph }\end{array}$ \\
\hline \begin{tabular}{|l|} 
Ability to \\
incorporate \\
visual elements \\
in \\
communication
\end{tabular} & $\begin{array}{l}\text { - Incorporate visual material that enhances } \\
\text { communication without detracting from it } \\
\text { - Incorporate various media appropriately } \\
\text { - Incorporate principles of visual design } \\
\text { appropriately }\end{array}$ \\
\hline \begin{tabular}{|l|} 
Ability to \\
develop \\
communication \\
through an \\
iterative process
\end{tabular} & $\begin{array}{l}\text { - Use iteration to clarify and amplify } \\
\text { understanding of issues being } \\
\text { communicated } \\
\text { - Use reflection to determine and guide self- } \\
\text { development }\end{array}$ \\
\hline
\end{tabular}

The approach of starting with a centralized committee, rather than examining existing assessment tools, was used for a few reasons. First, this allowed the Faculty to build capacity on existing expertise in outcomes development and assessment. Our instructors are not required to develop learning outcomes for their courses, so building expertise within a smaller group who can then make an impact on their respective units was a more suitable approach. This approach also allowed the faculty to develop a set of common global outcomes and indicators; it was determined that some commonality across programs was important, and that individual engineering programs can subsequently adjust, add or eliminate indicators that are not relevant to their program.

\section{ADAPTING EXISTING ASSESSMENT TOOLS TO ATTRIBUTE ASSESSMENT}

To actually measure whether our students are meeting these graduate attributes, however, tools either need to be developed from scratch, or adjusted for the purposes of attributes assessment. In this case, the second approach was chosen. Utilizing the existing assessment measures associated with an undergraduate thesis course for the measurement of the graduate attributes would maintain 
the integrity of the course, while allowing us to determine how well the current curriculum serves our needs.

As part of the adjustments to an outcome-based accreditation process, all programs are mapping the constructed indicators to existing or new course assessment tools, and identifying connections between the criteria on existing rubrics, and the indicators developed by the Graduate Attribute Committee.

\subsection{Initial Rubric Development}

One of the major challenges for a wide-ranging independent study style course such as this one lies in maintaining some degree of consistency in student workload and experience, as well as in supervisor expectations across projects. Two years prior to the introduction of the graduate attributes, an attempt to facilitate consistency in approach and assessment was launched, with the help of faculty from the Engineering Communication Program, through the development of a set of rubrics for course deliverables. In the case of the thesis course, it was particularly important that the rubrics allowed individual supervisors to emphasize project components most relevant to specific cases, and that the rubric did not standardize the projects to the detriment of the experience.

Simply choosing to employ rubrics, in a sense, bypasses the debate about the value of rubrics for assessment and instructional purposes. However, the many debates in the literature do help illuminate the value and weaknesses of rubrics, many of which have become important considerations in the development of these rubrics [12-14, 16]. Rubric design guidelines found in the literature were a starting point [8-9, 12-13], but the rubrics produced were highly specialized documents that needed to be needed to be (1) flexible enough to apply to a variety of engineering thesis projects, (2) authentically reflective of the learning objectives of the thesis course and (3) capable of facilitating common assessment practices and inter-rater reliability across a large number of supervisors who serve as primary assessors. A key consideration in the development and design of the rubric involved its usability; in satisfying many of the desired requirements for the rubric, it would have been easy to develop a highly complex and detailed document that would not be usable. The process behind the development of the rubrics is described further in [5], with the different iterations shown in Appendix A (Figure 1: 2009-2010 Thesis Document Rubric, Figure 2: 2010-2011 Thesis Document Rubric, Figure 3: 2011-2012 Thesis Document Rubric, Figure 4: 2011-2012 Rough Guide).

The first assessment rubric (Figure 1, Appendix A), created prior to and therefore without regard for the attributes assessment process, provided only short descriptions for each requirement within each section, limiting those requirements to a minimum within each section, especially for the content requirements. The requirements would describe the expectations for the sections, and supervisors were asked simply whether students met the requirement or not, or if they exceeded expectations for that requirement. In the next version (Figure 2, Appendix A), the first retooled for the attributes assessment process, four levels of performance per criteria were established. This version of the rubric allows for an initial pilot graduate attributes assessment, the results of which fed into more revisions of the rubric for the 2011-2012 school year (Figure 3, Appendix A).

\subsection{Adjusting the Assessment Tool for the Graduate Attribute Process}

Adjusting the assessment tool for the graduate attribute process included two major steps: mapping the rubric to the indicators developed associated with the communication and investigation attributes, and making further adjustments to the design of the rubric and the criteria within.

\section{2a Mapping Rubric Categories and Criteria to Graduate Attributes}

Because the rubric was initially developed for the assessment of an undergraduate thesis, its criteria differ from the precise parameters associated with investigation and communication in the graduate attributes. While a new rubric could have been created for the undergraduate thesis that reflected the exact indicator wording provided by the Graduate Attribute Committee, it remains important to maintain the essence of the thesis deliverables, and the specific priorities of the thesis supervisors and undergraduate program as a whole in the assessment process. As a result, there is still not a perfect one-to-one match between the rubric and the indicators, although improvements have been made on the pilot from 2010-2011 described earlier. The challenges of linking curriculum and assessment with graduate attributes, which include: the selection of appropriate assessment pieces; efficient methods of data collection and analysis; and suitable rubric design, have been discussed and documented widely by other institutions [2, 10-11].

While the attributes and subsequent indicators offer some general ways to assess the constructs, they are not rooted in the context of a particular assignment or discipline. It is important to note that the outcomes and indicators associated with each graduate attribute, which have been developed by a central committee, are relatively general and are out-of-context. When they are actually applied to the curriculum, we must allow for a certain degree of latitude in application and interpretation. 
To make an analogy, when we examine teacher knowledge, we consider "pedagogical knowledge" and "pedagogical content knowledge" as distinct; that is, teaching processes and outcomes change with disciplinary context. We argue that the same principle applies here, in that a graduate attribute in practice may present as distinct from a graduate attribute outside of a curricular context.

A sample of the mapping exercise is represented in Table 3, with the complete mapping results for Investigation and Communication shown in Appendix B. The numbers in the "rubric criteria" column reflect the graphed pilot data in section 4 . In considering how the attributes under study map to the thesis course, it is important to note that while all global outcomes (listed in the far left of the tables) must be measured, programs may choose which indicators (listed in the column second from the left) to use. Also, the graduate attributes will be mapped to various aspects of the curriculum, and so the thesis course serves as but one instance of at least 2-3 measurement points in the undergraduate program.

Table 3: Mapping Investigation skills to thesis rubric criteria (See Appendix B for complete mapping results for Investigation and Communication attributes)

\begin{tabular}{|c|c|}
\hline Investigation Attribute & Rubric Criteria (from \\
\hline Ability to define the problem & Figure 1) \\
\hline \multirow[t]{4}{*}{ Describe the previous work } & $\begin{array}{l}\text { (1) Establishes context } \\
\text { necessary to facilitate } \\
\text { thorough understanding of } \\
\text { thesis work in a } \\
\text { concise manner }\end{array}$ \\
\hline & $\begin{array}{l}\text { (4) Explains theoretical } \\
\text { concepts important to } \\
\text { understanding of thesis work }\end{array}$ \\
\hline & $\begin{array}{l}\text { (5) Identifies, summarizes } \\
\text { and synthesizes relevant } \\
\text { research in constructing an } \\
\text { understanding of current state } \\
\text { of field }\end{array}$ \\
\hline & $\begin{array}{l}\text { (6) Enables deeper } \\
\text { understanding of research } \\
\text { question/design problem } \\
\text { through analysis of research } \\
\text { in the field, indicating a path } \\
\text { for moving research forward }\end{array}$ \\
\hline $\begin{array}{l}\text { State the problem, its scope } \\
\text { and importance }\end{array}$ & $\begin{array}{l}\text { (2) Establishes a clear } \\
\text { research gap/design problem, } \\
\text { makes a convincing case for } \\
\text { the significance of proposed } \\
\text { research work }\end{array}$ \\
\hline State the objective of the work & $\begin{array}{l}\text { (3) Identifies goal for thesis } \\
\text { work that explicitly addresses } \\
\text { this gap/problem; provides } \\
\text { clear purpose statement }\end{array}$ \\
\hline \multicolumn{2}{|l|}{$\begin{array}{l}\text { Ability to devise and execute } \\
\text { a plan to solve the problem }\end{array}$} \\
\hline Select a set of tests to be & (7) Describes methods or \\
\hline
\end{tabular}

\begin{tabular}{|l|l|}
\hline conducted & $\begin{array}{l}\text { design in sufficient detail to } \\
\text { enable understanding of work } \\
\text { done }\end{array}$ \\
\cline { 2 - 2 } & $\begin{array}{l}\text { (8) Provides justification for } \\
\text { methods chosen or design } \\
\text { decisions made }\end{array}$ \\
\hline $\begin{array}{l}\text { Select, plan and apply the } \\
\text { methods for collecting the } \\
\text { results }\end{array}$ & $\begin{array}{l}\text { (7) Describes methods or } \\
\text { design in sufficient detail to } \\
\text { enable understanding of work } \\
\text { done }\end{array}$ \\
\cline { 2 - 2 } & $\begin{array}{l}\text { (8) Provides justification for } \\
\text { methods chosen or design } \\
\text { decisions made }\end{array}$ \\
\hline $\begin{array}{l}\text { Identify limitations of the } \\
\text { methods used and their impact } \\
\text { on the results. }\end{array}$ & $\begin{array}{l}\text { (8) Provides justification for } \\
\text { methods chosen or design } \\
\text { decisions made }\end{array}$ \\
\hline
\end{tabular}

In examining the most recent mapping of the investigation attribute indicators to the rubric criteria, we see a set of relatively clear links. However, there are some distinctions to consider. For example, take the indicators "Select a set of tests to be conducted" and "Select, plan and apply the methods for collecting the results". These indicators have been mapped to two rubric criteria: 1) Describes methods or design in sufficient detail to enable understanding of work done, and 2) Provides justification for methods chosen or design decisions made. Here, we have made an assumption that if the student can describe and justify methods, that they have likely selected them, or at least demonstrated the potential to make their own selections, though this may not be the case. In the case of the third global outcome, four indicators have been mapped to one of the rubric criteria, which suggests there may be challenges in demonstrating that we have met each of the distinct indicators.

However, as noted earlier, the process that we are following requires us only to demonstrate that we've met each of the global outcomes, and not each and every indicator noted. In examining the investigation attribute table, it is noted that the rubric criteria offer a higher degree of precision. For example, the indicator "Describe the previous work" is linked to four rubric criteria, all of which can be considered important dimensions of the indicator. By situating the graduate attribute within the thesis course and this assessment tool, we have provided a more precise description of what it means to "Describe the previous work". Given that the graduate attributes and their associated outcomes and indicators are new, we would argue that there is still fluidity at play. By using more specific assignment criteria, we may develop a better understanding of what each indicator means, which could have positive implications beyond the assessment of the thesis. While the graduate attribute process in our Faculty started as "top down", with a central committee outlining the outcomes and indicators, perhaps it is now time to use a bottom-up approach to refine, and better 
define the graduate attributes of the undergraduate engineer.

In the case of the Communication Attribute, we see more challenges. First, some of the communication indicators as developed by the Graduate Attribute Committee - for example, the incorporation of visual communication - were not initially assessed in the rubric, although this has been added to the 2011-12 iteration. The third global outcome, "Ability to develop communication through an iterative process”, has encouraged the addition of a new criterion, however we are not directly assessing the "reflection" component. Again, by contextualizing the graduate attributes within the thesis assignment, we can provide more precise descriptions of some of the indicators.

\section{2b Changes to the Assessment Tool}

While a flexible structure was initially developed for simplicity's sake, the adaptation of the rubric for graduate attributes assessment has called for a few changes. First, the quality descriptor labels were changed and given grade ranges, to encourage consistency of use and to bring the rubric in line with Faculty practice. More specifically, "poor”, “average”, "good” and "exceptional” became "fails” (0-60\%), “adequate” (60-70\%), “good” (70-80\%) and "exceeds expectations (80-100\%).

The graduate attribute process also called for more clear differentiation between levels of performance. As the data now had a secondary purpose, these calls came from all audiences, students and supervisors looking for a better sense of how to differentiate between sections, and from administrators looking to be clear on how these might be used in assessing graduate attributes, and ensuring that the attribute performance actually matched the description provided in the rubric. If included within the rubric, however, this information would make the rubric largely unusable - instead, we chose to develop a guide to the rubric that provided the differentiation between these levels - in other words, more specific descriptions of each thesis criteria at the four performance levels. This optional "rough guide" distinguished between levels of performance on a more granular level than the categories names could, focusing on identifying the "amount, intensity, or frequency" [2] of that trait that mapped to that level.

As noted earlier, some new criteria were added to the rubric to reflect the indicators associated with the graduate attributes - more specifically, "Incorporate principles of visual design appropriately" and "Use iteration to clarify and amplify understanding of issues being communicated.” Finally, communication to the supervisors was improved, to include a more thorough explanation of the thesis and graduate attribute assessment process.
The unique nature of the thesis course, presents problems for one important metric for rubric quality, as well as its ability to serve as an effective measure for student learning and performance, especially in the context of graduate attributes assessment: inter raterreliability. But given the specific nature of this course, effectively an independent study assessed almost exclusively by their supervisors, this problem will be difficult to negotiate. Two factors may help to mitigate this concern for in the context of graduate attributes assessment. First, the students are being assessed by full faculty members, rather than by teaching assistants. While the consistency of the data across the cohort may still be under question, each individual student is being given the professional judgment of an expert in the field. Second, our attempt to be more granular in the "rough guide" can be viewed an attempt to help create clarity across assessors. Writing descriptions of performance levels as a way of increasing inter-rater reliability has been discussed in previous research [9] and in fact, research has found that rubric design itself can offer the clarity needed for use by evaluators with substantial levels of agreement, potentially eliminating the need for formal norming [3]. However, it remains an important challenge to address in revisions of this assessment activity, and a limitation to the data derived from the project.

\section{PILOT DATA}

A set of pilot data was initially collected in 2011, based on the 2010-11 rubric. This experience was used to encourage some of the changes described in 3.2. After the thesis supervisors had completed the assessment of their students' work in May 2012, all rubrics were collected and data was compiled on each of the relevant indicators, using the mapping structure in tables A2A and A2B (Appendix B). This data compilation allowed us to review the competencies of the entire cohort on the two Graduate Attributes. This is represented by the following Figures, in which rubric criteria are mapped according to the numbering system in tables $\mathrm{A} 2 \mathrm{~A}$ and $\mathrm{A} 2 \mathrm{~B}$ and as described in section 3.2a: 


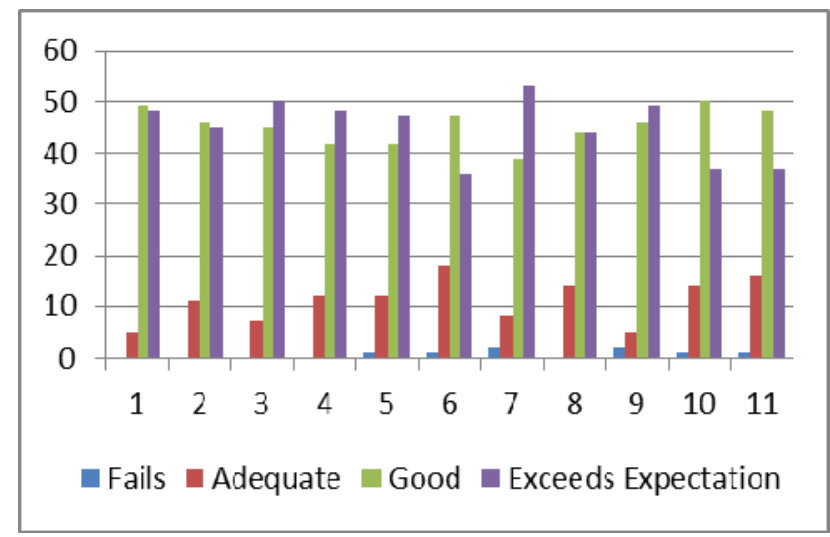

Figure 1: Investigation pilot data

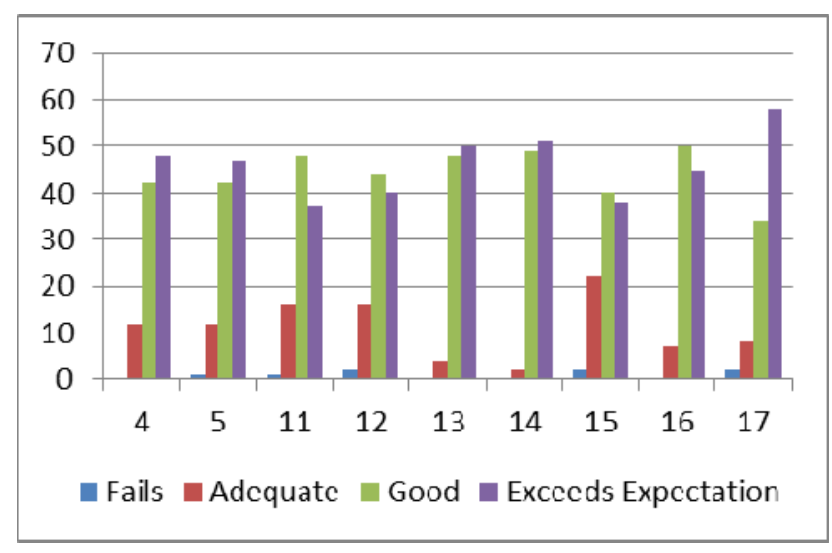

Figure 2: Communication pilot data

In Figures 1 and 2 above above, the total number of responses for each relevant criterion, and the four levels of competency, are plotted, based on a sample of 102 rubrics. From these results, we can see that thesis supervisors have generally assessed the final thesis reports as being of very high quality. This, in part, may be due to the grade ranges associated with the top two competencies ("Good" is 70-80, "Exceeds Expectation" is 80-100). However, this data does give us some indication of students' weaknesses - for example, Criteria 6, "Enables deeper understanding of research question/design problem through analysis of research in the field, indicating a path for moving research forward" and Criteria 15, "Demonstrates grammatically correct, coherent prose that concisely and clearly communicates complex topics in well designed paragraphs.”

\section{CONCLUSIONS}

Through the exercise of mapping the indicators to the rubric and determining deficiencies, alongside the process of collecting feedback from students and supervisors about the rubrics, as discussed earlier, we were able to determine where to make adjustments - to the rubric, and to the thesis experience as a whole. In addition to the changes noted earlier, we have also added a criterion to recognize the engineering and science knowledge base applied by the student, as this was cited as an important component to the supervisors.

As noted, we don't have perfect matching between the rubric and the indicators, and so one may ask, why not simply measure the indicators, as developed by the Graduate Attribute Committee, directly? We must consider the unique nature of our assessment pieces before taking this approach. As the specific global outcomes and indicators associated with the graduate attributes change over time, especially in these early stages of graduate attribute development, assignments will need to change, and we expect there to be an ongoing, iterative process between the development of accreditation-related outcomes and course-based assessment tools. Also, the outcomes and indicators developed by the Graduate Attribute Committee are, in some cases, quite general, and do not provide sufficient detail for direct insertion in an assignment rubric.

The question of the validity of the data derived from the rubric remains an important one. As stated above, the specific nature of the thesis course precludes any real promise of inter-rater reliability in the assessment and use of the rubric. We believe, however, that for the purposes of the thesis course as well as for graduate attributes assessment, this concern is somewhat mitigated by the fact that students are assessed by supervising professors experts in their respective fields - with the authority to speak to industry and academic expectations. Furthermore, we have attempted to develop a flexible and modular approach to rubric development that provides both appropriate generality - in the rubric itself - and detail - in the published "rough guide" - for different types of users.

In initially developing the rubric, we set out to create something that authentically described the thesis experience, but was flexible enough to allow thesis supervisors to apply their own needs, and the unique features of their project, in the rubric. When the use of the rubric is shifted away from scaffolding one-to-one feedback, to the measurement of a set of collaborativelyconstructed graduate attribute indicators, tensions arise, and adjustments need to be made. This work is inprogress, and further efforts will be placed on improving inter-rater reliability, and continuing to explore measures of validity that ensure the rubric is a good fit for both the individual assessments of the thesis experience, and the graduate attributes. Likewise, in measuring the graduate attributes, we must always consider that the attributes are to be contextualized in real learning experiences, and in turn, we can only demonstrate that students have met the attributes in the context of a specific assignment. 
However, there are also opportunities here, to use our curriculum to better define the learning outcomes associated with the graduate attributes, utilizing both a top-down and bottom-up approach to outcomes planning and measurement.

\section{References}

[1] D.K. Anthony, S.P. Magleby, C.D. Sorensen, B.R. Swan, and R.H. Todd, "A survey of capstone engineering courses in North America," Journal of Engineering Education, vol. 84, no. 2, pp. 165-174, 1995.

[2] T.W. Banta, J.P. Lund, K.E. Black, and F.W. Oblander, Assessment in Practice. San Francisco: Jossey-Bass. 1996.

[3] M.J. Bresciani, M. Oakleaf, F. Kolkhurst, C. Nebeker, J. Barlow, K. Duncan, and J. Hickmott, "Examining design and inter-rater reliability of a rubric measuring research quality across multiple disciplines,” Practical Assessment, Research \& Evaluation, vol. 14, no. 12, 2009. Available March $3^{\text {rd }}$ from: http://pareonline.net/pdf/v14n12.pdf.

[4] Canadian Engineering Accreditation Board (2010). Accreditation Criteria and Procedures. Available March $3^{\text {rd }}, 2012$ from http://www.engineerscanada.ca/e/files/acc_Manual_Accre ditation Procedures.pdf.

[5] Alan Chong and Lisa Romkey. "Evolving a Rubric for Use in Assessing Engineering Graduate Attributes in a Student Senior Research Thesis,” American Society for Engineering Education Conference. San Antonio, TX. June 10-13, 2012.

[6] A.J. Dutson, S.P. Magleby, C.D. Sorensen and R.H. Todd, "A review of literature on teaching engineering design through project-oriented capstone design courses," Journal of Engineering Education, vol. 86, no. 1, pp. 1728, 1997.

[7] B. Frank, S. Fostaty-Young, S. McCahan, P. Wolf, K. Ostafichuck, C. Watts, and N. Saleh, "Engineering graduate attribute development (EGAD) project.” Proceedings of the $2^{\text {nd }}$ Annual CEEA Conference: Memorial University St. John's, Newfoundland June 6-8 2011. Available March $3^{\text {rd }}, 2012$ from http://library.queensu.ca/ojs/index.php/PCEEA/article/vie $\underline{w / 3566}$.

[8] C.A. Mertler. "Designing scoring rubrics for your classroom," Practical Assessment, Research, \& Evaluation, vol. 7 no. 25. 2001 Available March 3 ${ }^{\text {rd }}, 2012$ from: http://www.pareonline.net/getvn.asp?v=7\&n=25.

[9] B.M. Moskal and J.A. Leydens, J.A. "Scoring rubric development: Validity and reliability," Practical Assessment, Research \& Evaluation, vol. 7, no.10, 2000. Available March $3^{\text {rd }}$, 2012: http://pareonline.net/getvn.asp?v=7\&n=10.
[10] J.A. Newell, K.D. Dahm, and H.L Newell, "Rubric development and inter-rater reliability issues in assessing learning outcomes," Chemical Engineering Education, vol. 36, no.3, pp. 212-15, 2002.

[11] J.A. Newell, H.L Newell, T.C. Owens, J. Erjavec, R. Hasan, and S.P.K. Sternberg, "Issues in developing and implementing an assessment plan in chemical engineering departments,” Chemical Engineering Education, vol. 34, no.3, pp. 268-271, 2000.

[12] W.J. Popham., "What's wrong - and what's right - with rubrics,” Educational Leadership, vol. 55, no. 2, pp. 7275, 1997.

[13] Y.M. Reddy and H. Andrade, "A review of rubric use in higher education,” Assessment \& Evaluation in Higher Education, vol. 35, no. 4, pp. 435-448, 2010.

[14] Y. Reed, "No rubric can describe the magic: Multimodal designs and assessment challenges in a postgraduate course for English teachers.” English Teaching: Practice and Critique, vol. 7, no. 3, pp. 26-41, 2008.

[15] J.A. Shaeiwitz, "Mining capstone engineering experiences for program assessment results," International Journal of Engineering Education, vol. 18, no. 2, pp. 193-198, 2002.

[16] E.D. Turley and C.W. Gallagher, “On the 'uses’ of rubrics: Reframing the great rubric debate,” English Journal, vol. 97, no. 4, pp. 87-92, 2008.

[17] H. Welch, D. Suri, and E. Durant, "Rubrics for assessing oral communication in the capstone design experience: Development, application, analysis and refinement," International Journal of Engineering Education, vol. 25, no. 5, pp. 952-961, 2009. 


\section{APPENDIX A: RUBRICS AND THE ROUGH GUIDE}

FINAL THESIS REPORT RUBRIC - I - ESC499

\section{Student}

Name:

Supervisor:

\begin{tabular}{|c|c|c|c|c|c|}
\hline Component & No & Yes & $\begin{array}{l}\text { Excep } \\
\text {-tional }\end{array}$ & Requirement & $\begin{array}{l}\text { Comments } \\
\text { (Please use back if necessary) }\end{array}$ \\
\hline \multirow[t]{3}{*}{ Introduction } & $\square$ & $\square$ & $\square$ & $\begin{array}{l}\text { Establishes context necessary to facilitate thorough } \\
\text { understanding of thesis work in a concise manner }\end{array}$ & \\
\hline & $\square$ & $\square$ & $\square$ & $\begin{array}{l}\text { Establishes a clear research gap, makes a convincing } \\
\text { case for the significance of proposed research work }\end{array}$ & \\
\hline & $\square$ & $\square$ & $\square$ & $\begin{array}{l}\text { Identifies goal for thesis work that explicitly addresses } \\
\text { the research gap; provides clear purpose statement }\end{array}$ & \\
\hline \multirow{3}{*}{$\begin{array}{l}\text { Literature } \\
\text { Review / } \\
\text { Background }\end{array}$} & $\square$ & $\square$ & $\square$ & $\begin{array}{l}\text { Explains theoretical concepts important to understanding } \\
\text { of thesis work }\end{array}$ & \\
\hline & $\square$ & $\square$ & $\square$ & $\begin{array}{l}\text { Identifies, summarizes, and synthesizes relevant } \\
\text { research in constructing an understanding of current } \\
\text { state of field }\end{array}$ & \\
\hline & $\square$ & $\square$ & $\square$ & $\begin{array}{l}\text { Enables deeper understanding of research question/ } \\
\text { design problem through analysis of research in the field, } \\
\text { indicating a path for moving research forward }\end{array}$ & \\
\hline \multirow[t]{3}{*}{$\begin{array}{l}\text { Methods and } \\
\text { Findings }\end{array}$} & $\square$ & $\square$ & $\square$ & $\begin{array}{l}\text { Describes methods or design in sufficient detail to enable } \\
\text { understanding of work done }\end{array}$ & \\
\hline & $\square$ & $\square$ & $\square$ & $\begin{array}{l}\text { Provides justification for methods chosen or design } \\
\text { decisions made }\end{array}$ & \\
\hline & $\square$ & $\square$ & $\square$ & $\begin{array}{l}\text { Results displayed clearly in organized manner, using } \\
\text { appropriate figures or graphics; key results highlighted }\end{array}$ & \\
\hline \multirow{3}{*}{$\begin{array}{l}\text { Discussion } \\
\text { and } \\
\text { Conclusions }\end{array}$} & $\square$ & $\square$ & $\square$ & Engages with and explains results intelligently & \\
\hline & $\square$ & $\square$ & $\square$ & $\begin{array}{l}\text { Identifies key claims to be drawn from results of research } \\
\text { or design evaluation, qualifies them appropriately }\end{array}$ & \\
\hline & $\square$ & $\square$ & $\square$ & $\begin{array}{l}\text { Outlines significance of research done, identifies } \\
\text { potential future work that arises from thesis work }\end{array}$ & \\
\hline \multirow{6}{*}{$\begin{array}{l}\text { Overall } \\
\text { Document } \\
\text { Design: }\end{array}$} & $\square$ & $\square$ & $\square$ & $\begin{array}{l}\text { Abstract concisely summarizes purpose, methods, key } \\
\text { results of research, and presents conclusions clearly }\end{array}$ & \\
\hline & $\square$ & $\square$ & $\square$ & $\begin{array}{l}\text { Document length, formatting, structure meets stated } \\
\text { requirements, and specific demands of thesis topic }\end{array}$ & \\
\hline & $\square$ & $\square$ & $\square$ & $\begin{array}{l}\text { Organized well, with content in discrete and appropriate } \\
\text { positions in paper, structure clearly laid out, transitions } \\
\text { that create flow in document }\end{array}$ & \\
\hline & $\square$ & $\square$ & $\square$ & $\begin{array}{l}\text { Demonstrates coherent prose that concisely and clearly } \\
\text { communicates complex topics in well designed } \\
\text { paragraphs }\end{array}$ & \\
\hline & $\square$ & $\square$ & $\square$ & $\begin{array}{l}\text { Demonstrates grammatical correctness and clarity in } \\
\text { sentence design }\end{array}$ & \\
\hline & $\square$ & $\square$ & $\square$ & $\begin{array}{l}\text { Provides clear attribution of ideas throughout paper using } \\
\text { a known referencing standard; uses references } \\
\text { effectively to help establish context, back claims, or } \\
\text { justify decisions }\end{array}$ & \\
\hline \multirow[t]{4}{*}{$\begin{array}{l}\text { Project } \\
\text { Experience }\end{array}$} & $\square$ & $\square$ & $\square$ & $\begin{array}{l}\text { Work has contributed to scholarship in field / made a } \\
\text { measurable impact }\end{array}$ & \\
\hline & $\square$ & $\square$ & $\square$ & $\begin{array}{l}\text { Demonstrated initiative and ownership of work } \\
\text { throughout thesis project }\end{array}$ & \\
\hline & $\square$ & $\square$ & $\square$ & $\begin{array}{l}\text { Demonstrated an ability to work independently and } \\
\text { manage their work plan, meeting all critical deadlines }\end{array}$ & \\
\hline & $\square$ & $\square$ & $\square$ & $\begin{array}{l}\text { Quality of effort and thesis work indicative of potential for } \\
\text { future research success }\end{array}$ & \\
\hline
\end{tabular}




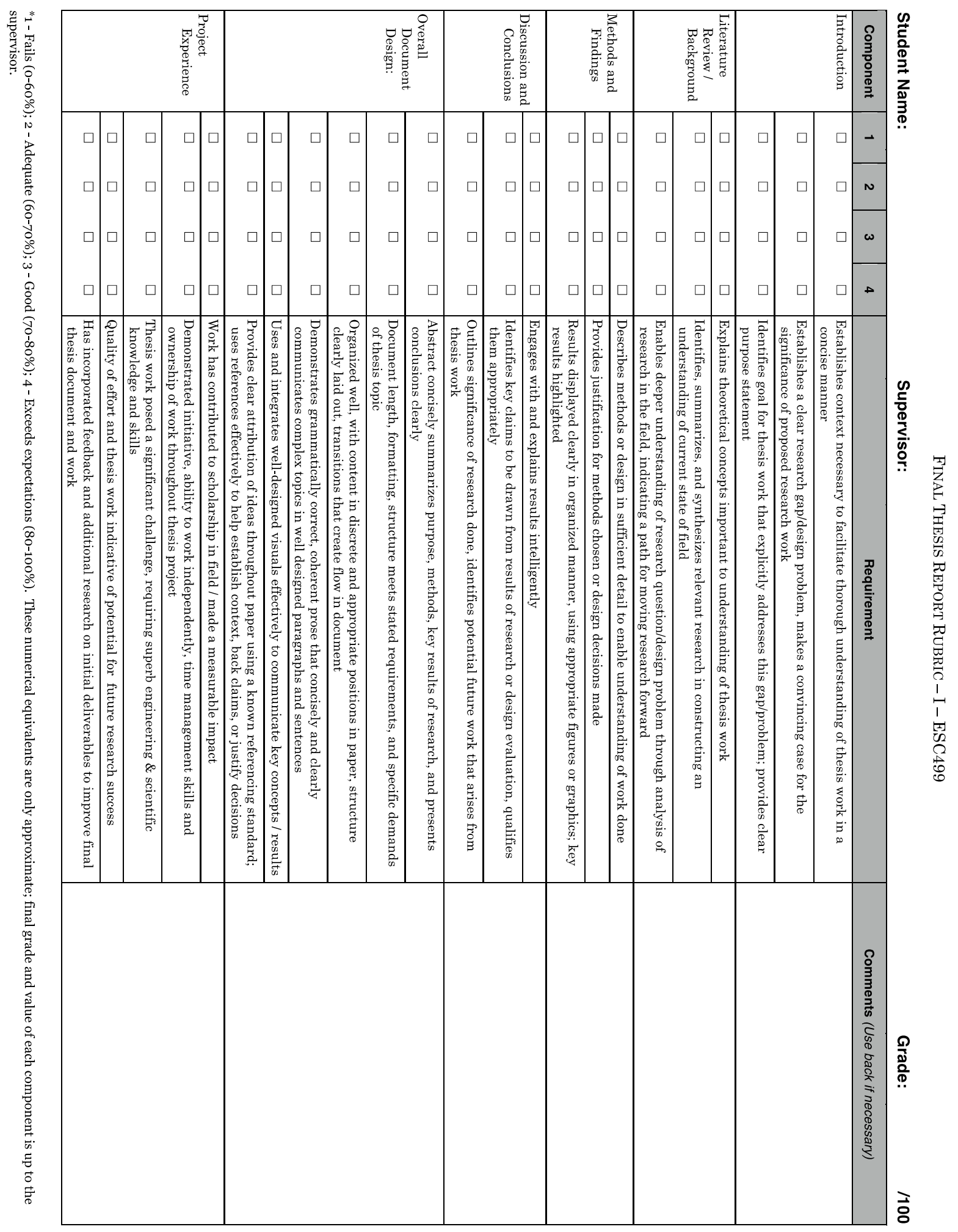

Figure 2: 2010-2011 Thesis document rubric 


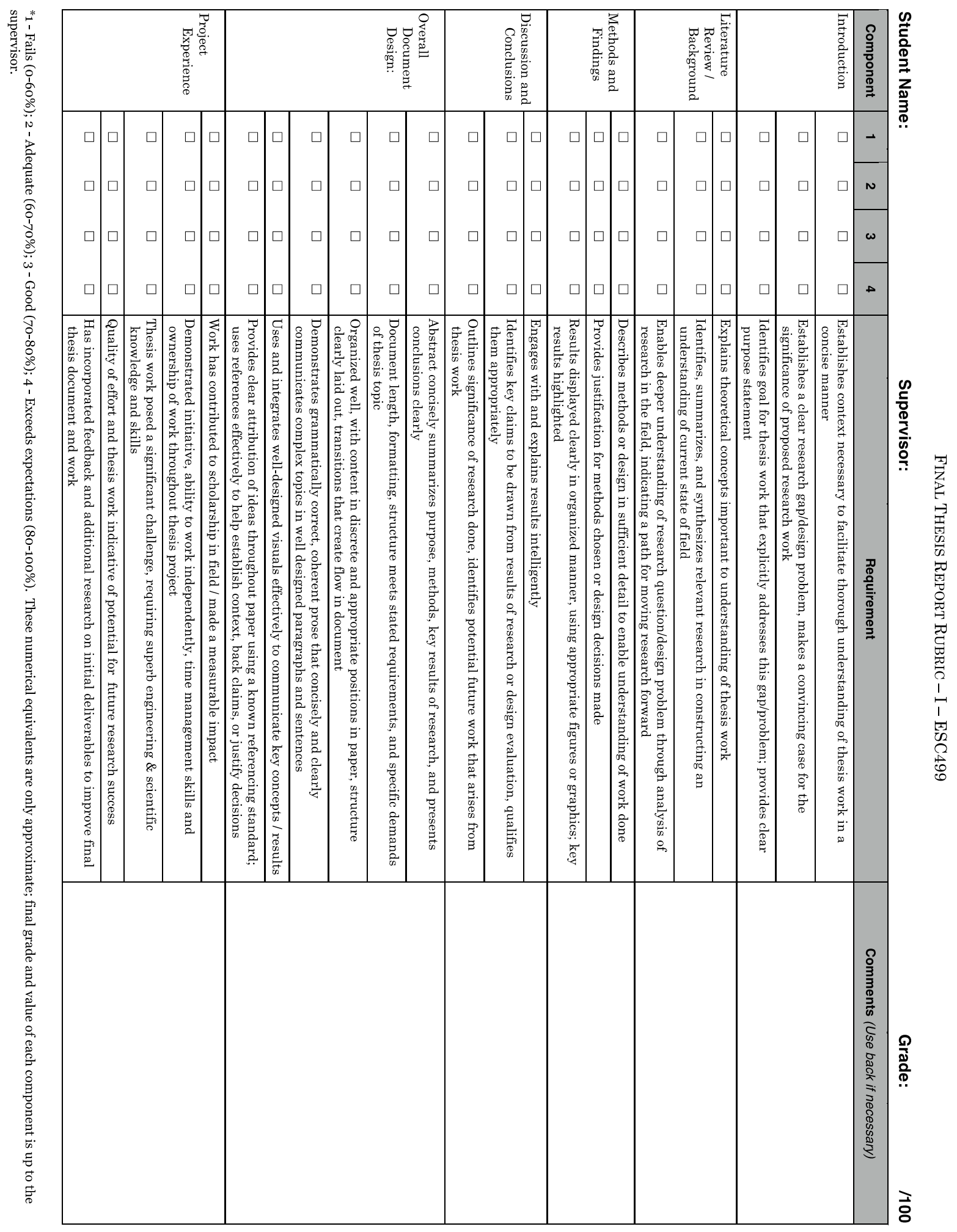

Figure 3: 2011-2012 Thesis document rubric 


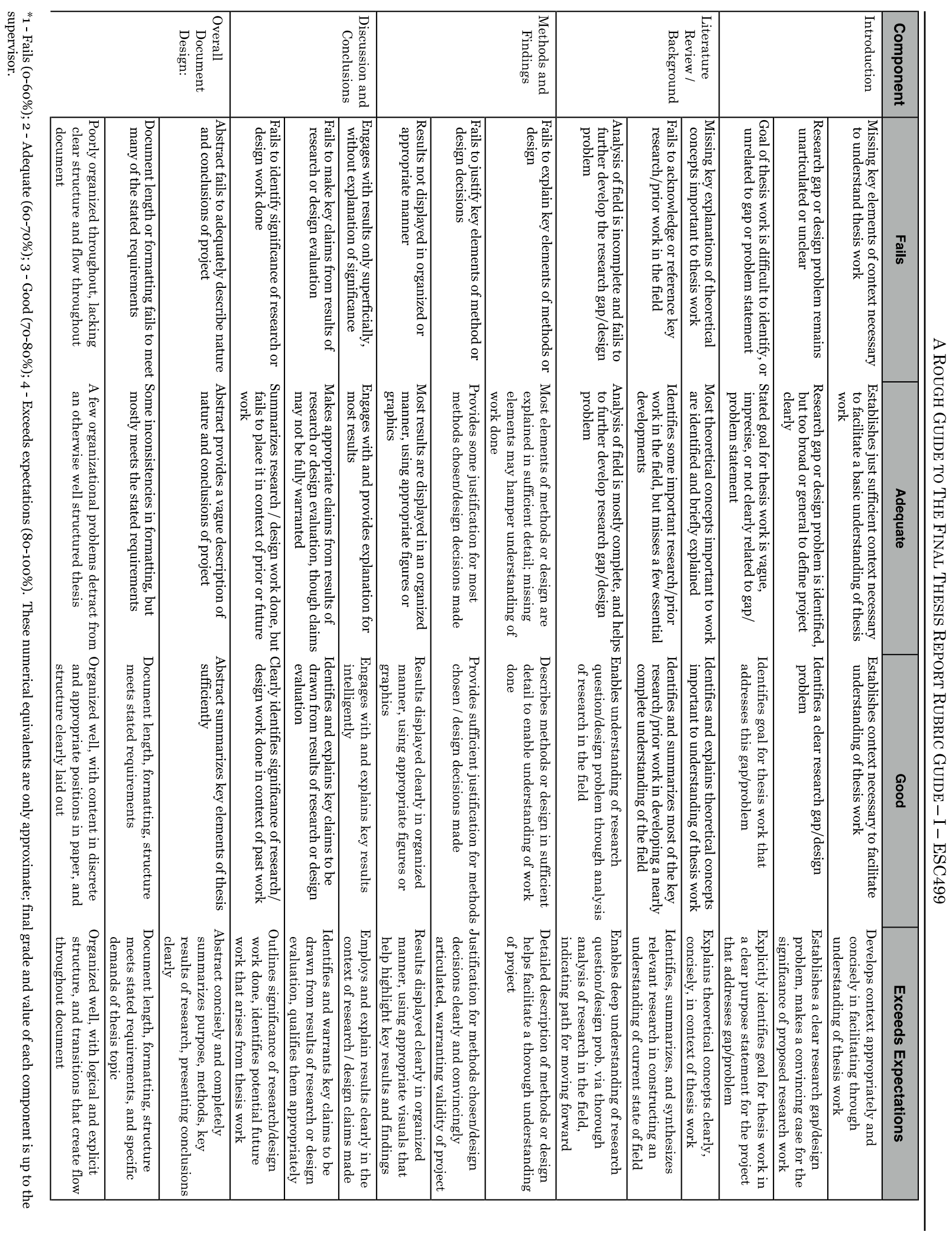

Figure 4: 2011-2012 Rough guide 
Figure 4: 2011-2012 Rough guide 
APPENDIX B: MAPPING THE ATTRIBUTES TO THE RUBRIC

Table A2A: Mapping Investigation skills to thesis rubric criteria

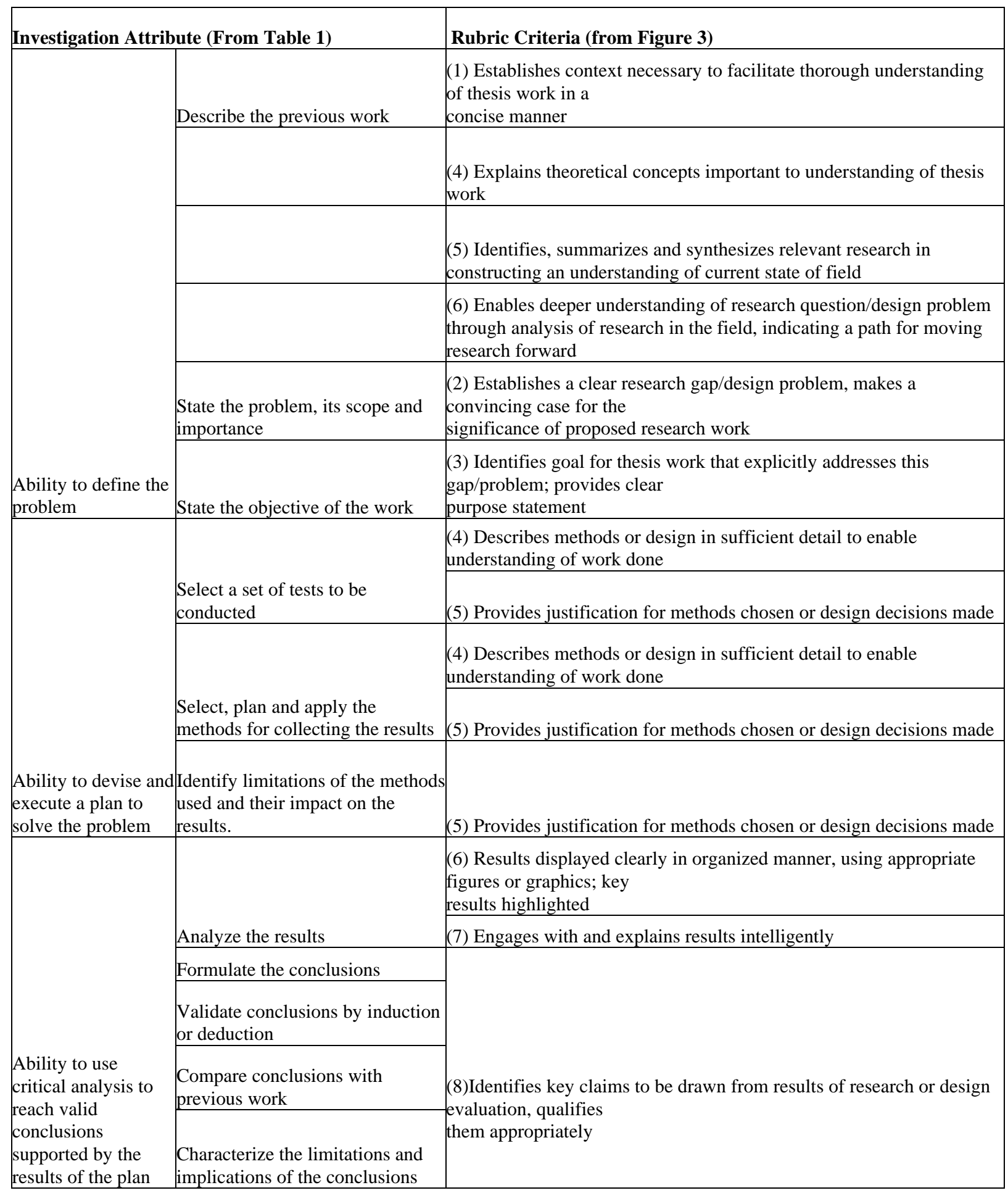


Table A2B: Mapping Communication skills to thesis rubric criteria

\begin{tabular}{|c|c|c|}
\hline \multicolumn{2}{|c|}{ Communication Attribute (From Table 2) } & \multirow[t]{2}{*}{ Rubric Criteria (From Figure 3) } \\
\hline & $\begin{array}{l}\text { Situate, in document or presentation, } \\
\text { the solution or design in the world of } \\
\text { existing engineering, taking into } \\
\text { account social, environmental, } \\
\text { economic and ethical consequences }\end{array}$ & \\
\hline & & $\begin{array}{l}\text { (4) Explains theoretical concepts important to understanding of } \\
\text { thesis work }\end{array}$ \\
\hline & $\begin{array}{l}\text { Recognize a credible argument } \\
\text { (reading) }\end{array}$ & $\begin{array}{l}\text { (5) Identifies, summarizes, and synthesizes relevant research in } \\
\text { constructing an } \\
\text { understanding of current state of field }\end{array}$ \\
\hline & Construct a credible argument in & $\begin{array}{l}\text { (11) Identifies key claims to be drawn from results of research or } \\
\text { design evaluation, qualifies } \\
\text { them appropriately }\end{array}$ \\
\hline & $\begin{array}{l}\text { written or spoken form - to } \\
\text { persuasively present evidence in } \\
\text { support of a claim }\end{array}$ & $\begin{array}{l}\text { (12) Outlines significance of research done, identifies potential } \\
\text { future work that arises from } \\
\text { thesis work }\end{array}$ \\
\hline \multirow{4}{*}{$\begin{array}{l}\text { Ability to identify } \\
\text { and credibly } \\
\text { communicate } \\
\text { engineering } \\
\text { knowledge }\end{array}$} & \multirow[b]{3}{*}{$\begin{array}{l}\text { Organize written or spoken material- } \\
\text { to structure overall elements so that } \\
\text { their relationship to a main point and } \\
\text { to one another is clear }\end{array}$} & $\begin{array}{l}\text { (13) Document length, formatting, structure meets stated } \\
\text { requirements, and specific } \\
\text { demands of thesis topic }\end{array}$ \\
\hline & & $\begin{array}{l}\text { (14) Organized well, with content in discrete and appropriate } \\
\text { positions in paper, structure } \\
\text { clearly laid out, transitions that create flow in document }\end{array}$ \\
\hline & & $\begin{array}{l}\text { (15) Demonstrates grammatically correct, coherent prose that } \\
\text { concisely and clearly communicates complex topics in } \\
\text { well designed paragraphs }\end{array}$ \\
\hline & $\begin{array}{l}\text { Create "flow" in document or } \\
\text { presentation - flow is a logical } \\
\text { progression of ideas, sentence to } \\
\text { sentence and paragraph to paragraph }\end{array}$ & $\begin{array}{l}\text { (14) Organized well, with content in discrete and appropriate } \\
\text { positions in paper, structure } \\
\text { clearly laid out, transitions that create flow in document }\end{array}$ \\
\hline $\begin{array}{l}\text { Ability to } \\
\text { incorporate visual } \\
\text { elements in } \\
\text { communication }\end{array}$ & $\begin{array}{l}\text { Incorporate visual material that } \\
\text { enhances communication without } \\
\text { detracting from it }\end{array}$ & $\begin{array}{l}\text { (16) Uses and integrates well-designed visuals effectively to } \\
\text { communicate key concepts/results }\end{array}$ \\
\hline
\end{tabular}




\begin{tabular}{|c|c|c|}
\hline & $\begin{array}{l}\text { Incorporate various media } \\
\text { appropriately } \\
\\
\text { Incorporate principles of visual design } \\
\text { appropriately }\end{array}$ & \\
\hline $\begin{array}{l}\text { Ability to develop } \\
\text { communication } \\
\text { through an iterative } \\
\text { process }\end{array}$ & $\begin{array}{l}\text { Use iteration to clarify and amplify } \\
\text { understanding of issues being } \\
\text { communicated } \\
\end{array}$ & $\begin{array}{l}\text { (17) Has incorporated feedback and additional research on initial } \\
\text { deliverables to improve final thesis document and work } \\
\end{array}$ \\
\hline
\end{tabular}

